\title{
An Eye on Opioids
}

\author{
Spencer P Thornton
}

University of Tennessee, Memphis, TN, US

DOI: https://doi.org/10.17925/USOR.2018.11.1.21

W hat do opioids have to do with ophthalmology? With recent developments in DNA research and gene modification, perhaps more than you might imagine. Naturally occurring opioids have been found in the DNA of certain milk cows, and it appears possible that the type of gene mutation that produces the opioid effect in milk and meat may also produce genetic abnormalities in the human genome, leading to hereditary ophthalmic syndromes, and diseases such as autism, Alzheimer's disease, heart disease and other chronic diseases. The identification, isolation, and subsequent modification of these genes would appear to be a step toward the eradication of the diseases associated with them.

\section{Keywords}

Opioids, genetic mutations, DNA, A1 milk, A2 milk, beta casomorphine, Cas9

Disclosure: Spencer P Thornton has no financial interests in the content of this article.

Review Process: This article is a short opinion piece and has not been submitted to external peer reviewers.

Authorship: All named authors meet the International Committee of Medical Journal Editors (ICMJE) criteria for authorship of this manuscript, take responsibility for the integrity of the work as a whole, and have given final approval to the version to be published.

open Access: This article is published under the Creative Commons Attribution Noncommercial License, which permits any noncommercial use, distribution, adaptation, and reproduction provided the original author(s) and source are given appropriate credit. (c) The Authors 2018

Received: December 13, 2017

Published Online: March 26, 2018

Citation: US Ophthalmic Review, 2018;11(1):21-23

Corresponding Author: Spencer Thornton, MD,

FACS, 5031 Hillsboro Pike, Suite 314, Nashville,

TN 37215, US. E: sthornton@biosyntrx.com

Support: No funding was received in

the publication of this article.
What started my research in genetic mutations in cows leading to different types of milk was my interest and research in chronic diseases, possibly caused by or related to genetic chromosomal mutations. My first involvement in this type of research was in 1965-1967, when I was researching my textbook Ophthalmic Eponyms: An Encyclopedia of Named Signs, Syndromes and Diseases in Ophthalmology.

In this book, I described more than 200 syndromes and diseases that were familial and possibly the result of genetic mutations. Examples include Adies syndrome, Albers-Schönberg disease, Albright's syndrome, Alport's syndrome, Alström-Hallgren syndrome, Alzheimer's disease, Amalric's syndrome, Andogski's syndrome, Angelvecci's syndrome, Apert's syndrome, Aubineau-Lenoble syndrome, Axenfeld-Schüremberg syndrome, Berdet-Biedl syndrome, Barlenwerfer's syndrome, Basedow's disease, Bassen-Kornzweig syndrome, Batten-Mayor syndrome, Behr's disease, Benjamin's syndrome, Best's macular degeneration, Biber-Haab-Dimmer corneal dystrophy, Bielschowsky-Jansky syndrome, Bieman's syndrome, and many more. ${ }^{1}$

My current study began as a search for possible genetic links for cures to diseases such as Alzheimer's disease, autism, diabetes, heart disease and other diseases of aging, and to identify diseases and syndromes that, with today's advanced technology, might possibly respond to deliberate alteration in genes, providing a cure or amelioration.

What I discovered was a number of studies linking not only genetic connections to abnormal conditions in humans, but also to genetic alterations in other animals, such as cattle. I discovered articles on genetic alterations in proteins in milk, serum, hormones, and enzymes. Some of these appear to have the potential to affect brain function, reproduction, and resistance to disease.

Most people are familiar with organic milk as a healthier alternative to industrial (non-organic) milk, that has been accused of being laden with antibiotics and stress hormones. Organic milk is essentially antibiotic- and hormone-free, and healthier because the cows are fed grass or organically cultivated fodder. Still, it appears that the breed of cow may matter more than its feed.

\section{Opioids in milk and beef}

Our concern is that an opioid, beta-casomorphine-7 (BCM-7) is present in A1 cow milk. Cows producing A1 milk include breeds such as Holstein, Friesian, British Shorthorn, and Ayrshire that originated in northern Europe. Cows producing A2 milk include such dairy breeds as Guernsey, Jersey, and beef cattle breeds such as Charolais and Limousin, which developed in the Channel Islands and Southern France.

The percentage of $\mathrm{A} 1$ and $\mathrm{A} 2$ beta-casein protein varies between herds of cattle and also between countries. Up to $70 \%$ of Holsteins and Ayrshires, most commonly found in the US, Australia, New Zealand and Europe produce the A1 type beta-casein protein in their milk. 
A2 cow milk comes from the older cattle breeds such as desi Indian cows or African cows that produce protein in their milk with an amino acid called proline. In hybrid breeds, the proline amino acid mutated to histidine due to gene alteration thousands of years ago, as cattle were being taken north into Europe. The proline at position 69 was replaced by histidine, with the mutation subsequently spreading widely throughout herds in the Western world, through interbreeding. ${ }^{2}$

African and Asian cattle continue to produce primarily $\mathrm{A} 2$ beta-casein milk, and, on average, more than $70 \%$ of Guernsey and Jersey cows produce milk with predominantly $\mathrm{A} 2$ protein.

\section{A1 and A2 milk-what is the difference?}

Most industrial milk contains both A1 and A2 beta-casein, but A2 milk contains predominantly $\mathrm{A} 2$ beta-casein. When $\mathrm{A} 1$ beta-casein is digested, it releases a peptide (protein fragment of a short chain of amino acids) called beta-casomorphin-7 (BCM-7), with seven amino acids at position 69 in its 209 peptide sequence that is an opioid found in a high percentage of milk produced by type $\mathrm{A} 1$ cows. ${ }^{3}$

BCM-7 is not active in $\mathrm{A} 2$ beta-casein because proline (an $\alpha$-amino acid) is strongly bonded to the small protein fragment $\mathrm{BCM}-7$, preventing it from being released into the milk produced by $\mathrm{A} 2$ cows. On the other hand, histidine in $\mathrm{A} 1$ cows holds a weak bond with $\mathrm{BCM}-7$, so it is easily released in the gastrointestinal tract of animals, and can enter the human body upon consumption of $\mathrm{A} 1$ milk and interact with the digestive system and circulation. ${ }^{4}$

There appears to be a high degree of correlation between $\mathrm{A} 1$ beta-casein and heart disease and diabetes, which has raised the possibility that the type of casein in the fresh milk supply could possibly be a risk factor. This is under investigation.

Interest in the distinction between $\mathrm{A} 1$ and $\mathrm{A} 2$ beta-casein proteins began in the early 1990 s via epidemiological research and animal studies. Initially conducted by scientists in New Zealand, they found correlations between the prevalence of milk with A1 beta-casein proteins in some countries and the prevalence of various chronic diseases in those countries. The research generated interest in the media, among some in the scientific community and entrepreneurs. If it is indeed true that BCM-7 could harm humans, it would be an important public health issue as well as a commercial opportunity. ${ }^{4}$

\section{What does all this mean?}

An emerging body of research suggests that many of the one in four Americans who exhibit symptoms of lactose intolerance could instead be unable to digest A1 beta-casein, most often found in milk from highproducing Holstein cows favored by American and some European industrial dairies. A number of observations indicate that many people who cannot digest A1 milk are able to digest A2 milk.

Surveys of $\mathrm{A} 1$ beta-casein consumption confirm the possibility that intensive dairy cattle breeding may have favored a genetic variant in milk with adverse effects in humans. More than 100 studies suggest links between the A1 protein and a range of health conditions-from heart disease to diabetes to autism — though evidence to date is far from conclusive. Further animal research and clinical trials will be needed to compare disease risks. ${ }^{5}$
Some theorize that peptides such as $\mathrm{BCM}-7$ might play a role in the development of autism. One study of infants found higher levels of BCM-7 in those who were fed cow's milk, compared to those who were breastfed. However, studies do not support all of the proposed mechanisms. BCM-7 was strongly associated with an impaired ability to plan and perform actions, and another study suggested that drinking cow's milk could worsen behavioral symptoms in autistic children, and despite the suggested possibility, there is no conclusive evidence about the effects of A1 milk on autism, and the issue needs to be studied further. ${ }^{6}$

Concern among medical ethicists and investors about this research seems unjustified. A review of published research in this current study reveals that there are no conclusive claims made about milk and health risks. All statements are conditioned by the caveat, "the evidence to date is far from conclusive."

Tobacco and cancer research and its opposition by the tobacco industry over the past six or seven decades appears similar to the dairy industry's reaction to this current research.

Several commercial dairymen and distributers were questioned about the issue of A1 and A2 milk, and it was discovered that financing of almost all dairy associations are, like the financing of medical associations and legal associations, non-profit and solely for the promotion of the interests of the industry. No evidence of federal funding was found.

\section{Genetic engineering}

A medical technique referred to as "gene editing" has been developed in China. Known as CRISPR-Cas9, it was developed early in the $21^{\text {st }}$ century and US trials are set to begin sometime in $2018 .{ }^{7}$

This innovative procedure works by injecting modified cells into patients with aggressive disease to improve immune cells' ability to attack abnormal genes such as those in cancer and certain inherited conditions. It works by removing, adding, or altering sections of the DNA sequence.

Cas9 is an enzyme that acts as "molecular scissors" that can cut the two strands of DNA at a specific location in the genome so that bits of DNA can then be added or removed.

An RNA sequence piece called a guide sequence (gRNA) is inserted into the existing scaffold of RNA. This scaffold part binds to DNA and the predesigned sequence "guides" Cas9 to the right part of the genome, making sure that the Cas9 enzyme cuts at the right point in the genome. The modified gene then fills this space, completing the DNA strand.

The evidence suggests the possibility that diseases such as Alzheimer's disease, type 2 diabetes, and other degenerative conditions may be traced to mutations in genes. It would follow that with current science one could identify the abnormal gene characteristic of conditions such as Alzheimer's and replace it with normal genes, effecting cure or amelioration.

\section{Summary}

In our search for increased longevity, it appears that lifestyle changes, proper nutrition including nutritional supplements and regular exercise are now joined by scientific breakthroughs like manipulation of human genes and DNA. $\square$ 
1. Thornton SP, Ophthalmic Eponyms: An Encyclopedia of Named Signs, Syndromes and Diseases in Ophthalmology, Birmingham, AL: Aesculapius Publishing Company, 1967.

2. Woodford K, Devil in the milk: illness, health and politics: $A 1$ and A2 milk, London: Craig Potton Publishing, 2009.

3. Coste M, Tome D. Milk peptides with physiological activities. II. Opioid and immunostimulating peptides derived from milk proteins. Le Lait. 1991;71:241-7

4. Kurek M, Przybilla B, Hermann K, Ring J. A Naturally Occurring Opioid Peptide from Cow's Milk, Beta-Casomorphine-7, Is a Direct Histamine Releaser in Man. Int Arch Allergy Immunol. 1992;97:115-20.

5. Laugesen M, Elliott R. Opioids in milk. NZ Med J. 2003; 116:1168. 6. Greger M, Cow's Milk-Induced Infant Apnea With Increased
Serum Content Of Bovine Beta Casomorphin: Cow's MilkInduced Infant Apnea With Increased Serum Content Of Bovine Beta Casomorphin. J Pediatr Gastroenterol Nut. 2011;52:772-5

7. Vidyasagar $A$, What Is CRISPR? 2017. Available at: www.livescience.com/58790-crispr-explained.htm (accessed January 18, 2018). 